\title{
Diatom Assemblages from Holocene Sediments of the Kola Peninsula
}

\author{
O. S. Olyunina, E. I. Polyakova, and F. A. Romanenko \\ Presented by Academician A.P. Lisitsyn October 8, 2007
}

Received October 17, 2007

DOI: $10.1134 / \mathrm{S} 1028334 \mathrm{X} 08090031$

The Kola Peninsula is one of the key areas for the study of postglacial development of northern Europe. The repeated formation of ice shields during the Pleistocene determined the peculiar features of the relief, structure of Quaternary sediments, and recent landscapes of the peninsula. The paleogeographic reconstructions available for the last 10-11 ka are based on results of the palynological analysis of lacustrine and boggy sediments [3-5, 9-11] and, to a lesser extent, on diatoms from the lacustrine sediments $[7,8]$. In this communication, we present the first data on diatom assemblages from peat sections of the central Kola Peninsula and their detailed radiocarbon ages. The high sensitivity of lacustrine-boggy ecosystems to environmental changes made it possible to define several Holocene diatom assemblages and to correlate their succession with regional climatic events and variations in the local base level.

The samples collected by the scientific teams from the geography department of Moscow State University in the eastern piedmonts of the Khibiny Mountains during field work in the years 2000-2006 served as material for this study (Fig. 1a). Over 20 peat sections were studied. Diatom assemblages were examined in four cores of lacustrine-boggy sediments from the western coast of Umbozero Lake and the Tul'jok River valley (Figs. 1a, 1b). Radiocarbon ages for peat and underlying sapropels were obtained at the Geological Institute of the Russian Academy of Sciences (table).

Geomorphological positions of the sections. The piedmonts of the Khibiny Mountains represent a glacial-fluvioglacial plain with lakes and fluvial-fluvioglacial deltas. Umbozero Lake is surrounded by four rock-defended and filltop terraces located 1 to $25 \mathrm{~m}$ above the present-day lake level (Figs. 1a, 1b). The surfaces of terraces and bottoms of numerous depressions

Geography Department, Lomonosov Moscow State University, Moscow, Russia;

e-mail: o.olyunina@mail.ru and lakes are partly swamped. The central part of the Kola Peninsula is characterized by development of herbaceous-Sphagnum mesotrophic, sedge-moss eutrophic, flat bumpy mire, and aapa mire swamps $[2,6]$. According to drilling data, the peat thickness ranges from 0.5 to $3 \mathrm{~m}$. The permafrost is observed only in cores of peat mounds.

Age and composition of sediments. According to radiocarbon measurements (table), lacustrine-boggy sediments were accumulating during practically the entire Holocene. Preboreal and Boreal sediments were recovered by Core 2002-1-1 on the fourth terrace of Umbozero Lake (Fig. 2). Their section is composed of blue-gray sandy massive clays grading upward through the section to light brown sapropel with detritus intercalations. The early Atlantic period is represented by sapropel preserved largely among sediments of residual lakes at the surfaces of the second-fourth Umbozero Lake terraces (cores 2002-1-1, 2001-4, and others). Younger sediments are usually peat, peatlike sapropel, and sapropel (in the lower part of the section). Peat dated back to the mid-Atlantic period contains abundant remains of arboreal and frutescent vegetation and is characterized by the high decomposition degree of herbaceous plants. Some sections (cores 2002-1-1 and 2002-YUG-D) demonstrate hiatuses in sediments corresponding to the period of 7.2 to $4.5 \mathrm{ka}$. The sediments of the terminal Atlantic-initial Subboreal period are represented in all the sections by thick peat sequences, while the upper Subboreal-basal Subatlantic sediments are either missing or fragmentary. Peat accumulated during the second half of the Subatlantic period crowns all the examined peat sections.

The composition of diatom assemblages. All the sections contain diverse (approximately 400 species and varieties, in total) and abundant (up to 1 billion valves/g of dry sediment) diatom assemblages dominated by representatives of the genera Eunotia (E. faba, E. exigua, E. triodon, E. parallela, E. lapponica, E. arcus, and others) typical of high-latitude swamps and Pinnularia $(P$. viridis, $P$. microstauron, $P$. stomatophora, and others) as well 


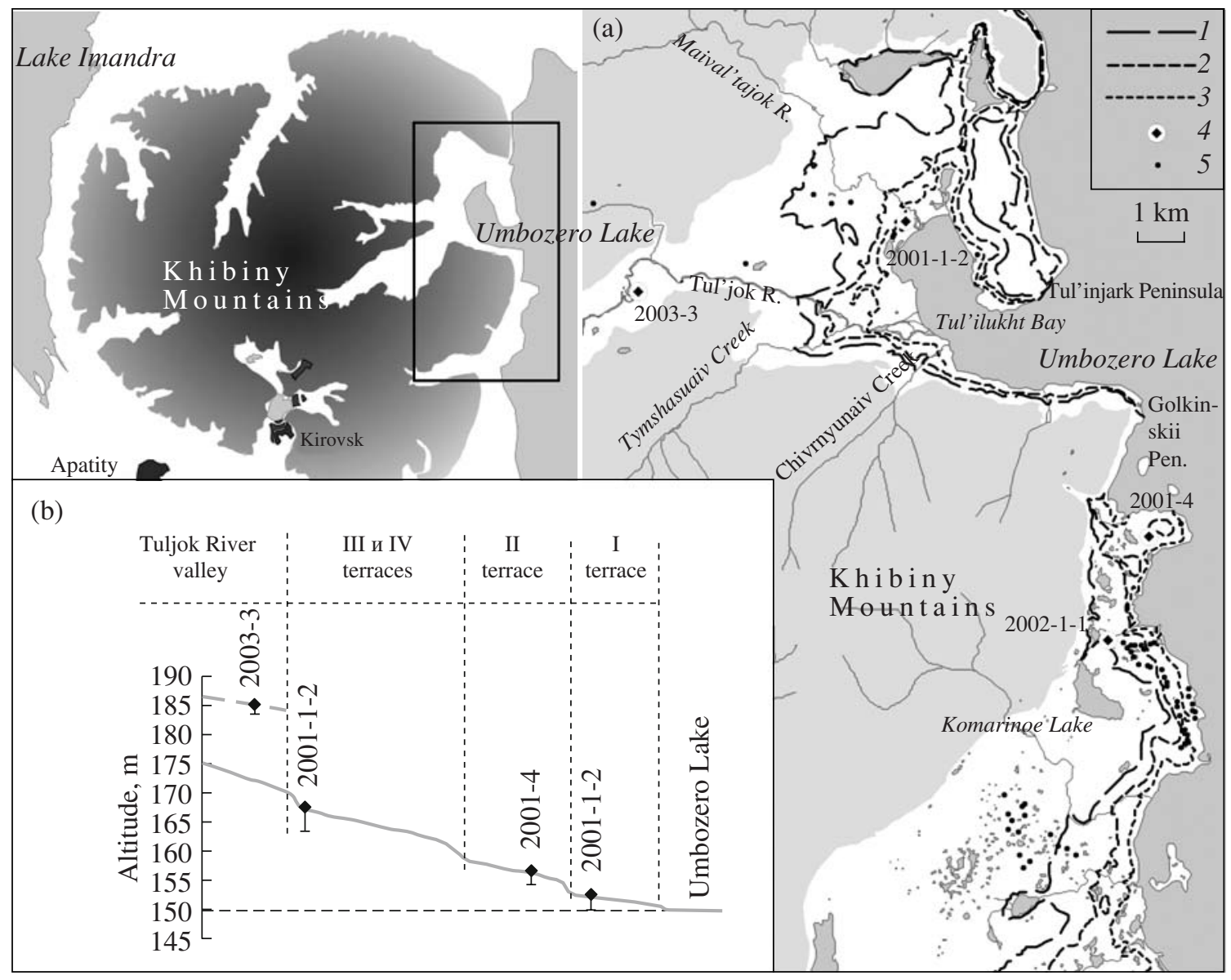

Fig. 1. Schematic map of the study area and location of examined sections of lacustrine-boggy sediments. Boundaries of the Umbozero Lake terraces: (1) III and IV, (2) II, (3) I; (4) cores with examined diatom assemblages; (5) other cores.

as acidophilic forms (Brachysira spp., Frustulia rhomboides var. saxonica, Tabellaria flocculosa, and others) characteristic of acid waters of dystrophic lakes and bogs.

The diatom assemblages from Preboreal and Boreal sediments corresponding to the period of $10-8 \mathrm{ka}$ ago were studied in Core 2002-1-1 (diatom zones (DZ) I-III, Fig. 2), where they are characterized by the maximal abundance (up to 1 billion valves/g) and diversity. The dominant species are Fragilaria representatives (F. construens with varieties, $F$. pinnata, $F$. lapponica, and others) indicating accumulation of sediments in a shallow basin. Diatoms of the initial Atlantic period (8$7 \mathrm{ka}$ ago) are represented in core sections 2002-1-1 (DZ IV) and 2001-4 (DZ I) by species belonging to the genera Barachysira, Pinnularia, Eunotia, and by Frustulia rhomboides var. saxonica and taxonomically close to the benthic flora of small dystrophic basins. The diatom assemblage of the middle Atlantic period (7.0 to $5.5 \mathrm{ka}$ ago) is of very low diversity mono- or oligodominant with prevalence of eurytopic species Eunotia faba and E. exigua (Core 2001-4, DZ II-III) most resistant to different environments. In sediments of late Atlantic-early Subboreal age (5.5-3.2 ka ago), diatoms are abundant and highly diverse being dominated by spe- cies of the genera Eunotia, Brachysira, Cymbella, and Tabellaria (Core 2003-3, DZ II-III; Core 2002-1-1, DZ V; Core 2001-4, DZ IV; Core 2001-1-2, DZ I-II), which indicates amelioration of habitat conditions, primarily higher moisture. The second half of the Subboreal period (the last 3.2 ka years) is characterized by lower taxonomic diversity of diatom assemblages and a dominant role of typical ubiquitous bog species: Eunotia exigua, E. lapponica, P. microstauron, P. viridis, Encyonema minutum (Core 2003-3, DZ III; Core 2002-1-1, DZ VI; Core 2001-4, DZ V; Core 2001-1-2, DZ III-V). Boreal species in these assemblages are replaced by northern Alpine forms: Eunotia praerupta var. muscicola, E. faba, E. incisa, Brachysira brebissonii, and others.

The analysis of Holocene lacustrine-boggy diatom assemblages from peats of the central Kola Peninsula and their radiocarbon ages allow four main periods of their formation to be defined.

The Preboreal and Boreal periods (10 to $8 \mathrm{ka}$ ago). The diatom assemblages from the lower part of the section (Core 2002-1-1) were formed in a shallow bay of Umbozero Lake, which was, likely, larger after deglaciation as compared with its present-day size and its shoreline corresponded to the rear suture of the fourth 
Radiocarbon ages of lacustrine-bogy sediments of the eastern Khibiny Mountains and western coast of Umbozero Lake

\begin{tabular}{|c|c|c|c|c|c|}
\hline Core & Altitude, $\mathrm{m}$ & Depth, cm & ${ }^{14} \mathrm{C}$ age, $\mathrm{ka}$ & Material & Laboratory number \\
\hline 2000 & 152.5 & $55-58$ & $1470 \pm 50$ & Peat & GIN-11185 \\
\hline 2001-1-1 & 152.5 & 86 & $3000 \pm 40$ & Peat & GIN-11756 \\
\hline $2001-1-2$ & 152 & $\begin{array}{l}150-160 \\
206-216 \\
216-226\end{array}$ & $\begin{array}{l}3880 \pm 70 \\
4480 \pm 50 \\
4560 \pm 80\end{array}$ & $\begin{array}{l}\text { Peatlike sapropel } \\
\text { Sapropel } \\
" \prime\end{array}$ & $\begin{array}{l}\text { GIN-11758 } \\
\text { GIN-11760 } \\
\text { GIN-11761 }\end{array}$ \\
\hline $2001-1-5$ & 152 & $160-170$ & $6490 \pm 110$ & Peat & GIN-11764 \\
\hline $2001-2$ & 175 & $\begin{array}{r}90-100 \\
170-180\end{array}$ & $\begin{array}{l}6220 \pm 70 \\
7320 \pm 70\end{array}$ & $\begin{array}{l}\text { Peat } \\
"\end{array}$ & $\begin{array}{l}\text { GIN-11765 } \\
\text { GIN-11767 }\end{array}$ \\
\hline $2001-3-1$ & 162 & $165-175$ & $6450 \pm 150$ & $"$ & GIN-11768 \\
\hline 2001-4 & 156 & $\begin{array}{r}90-100 \\
130-140 \\
170-180 \\
170-185\end{array}$ & $\begin{array}{l}3340 \pm 80 \\
5180 \pm 200 \\
6450 \pm 70 \\
7180 \pm 120\end{array}$ & $\begin{array}{l}" \\
" \\
\prime \\
\text { Sapropel }\end{array}$ & $\begin{array}{l}\text { GIN-11772 } \\
\text { GIN-11773 } \\
\text { GIN-11774 } \\
\text { GIN-11775 }\end{array}$ \\
\hline $2001-5$ & 152 & $110-120$ & $6000 \pm 40$ & Peat & GIN-11771 \\
\hline $2001-7$ & 223 & $290-350$ & $6770 \pm 70$ & Peat & GIN-11777 \\
\hline $2001-8-1$ & 209 & $380-400$ & $8230 \pm 180$ & $"$ & GIN-11778 \\
\hline $2002-8-2$ & 209 & $450-460$ & $8060 \pm 160$ & Sapropel & GIN-11928 \\
\hline 2002-1-1 & 167 & $\begin{array}{r}90-105 \\
160-170 \\
230-240 \\
245-260 \\
260-270 \\
290-300\end{array}$ & $\begin{array}{l}1560 \pm 70 \\
3250 \pm 70 \\
3980 \pm 90 \\
4500 \pm 70 \\
7020 \pm 100 \\
9270 \pm 250\end{array}$ & $\begin{array}{l}\text { Peat } \\
" \\
\prime \prime \\
" \\
\text { Sapropel } \\
\prime \prime\end{array}$ & $\begin{array}{l}\text { GIN-12262 } \\
\text { GIN-12263 } \\
\text { GIN-12264 } \\
\text { GIN-12265 } \\
\text { GIN-12266 } \\
\text { GIN-11776 }\end{array}$ \\
\hline 2002-YUG-D & 212 & $\begin{array}{l}320-330 \\
420-435 \\
455-470\end{array}$ & $\begin{array}{l}1920 \pm 150 \\
4240 \pm 150 \\
7770 \pm 200\end{array}$ & " & $\begin{array}{l}\text { GIN-12269 } \\
\text { GIN-12270 } \\
\text { GIN-12271 }\end{array}$ \\
\hline 2002-YUG-E & 206 & $285-300$ & $5820 \pm 90$ & Peat & GIN-12272 \\
\hline 2002-YUG-F & 202 & $190-200$ & $4200 \pm 170$ & Sapropel & GIN-12273 \\
\hline 2002-YUG-G & 197 & $125-135$ & $4210 \pm 120$ & Sapropel & GIN-12274 \\
\hline 2002-YUG-I & 184 & $350-365$ & $7300 \pm 200$ & $"$ & GIN-12276 \\
\hline 2002-YUG-K & 182 & $250-265$ & $7800 \pm 130$ & $"$ & GIN-12278 \\
\hline 2003-1 & 159 & $\begin{array}{l}90-100 \\
15-20 \\
10-15\end{array}$ & $\begin{array}{l}8450 \pm 40 \\
3100 \pm 40 \\
1530 \pm 70\end{array}$ & $\begin{array}{l}\text { Peat } \\
" \\
"\end{array}$ & $\begin{array}{l}\text { GIN-12644 } \\
\text { GIN-12646 } \\
\text { GIN-12647 }\end{array}$ \\
\hline $2003-2$ & 152 & $20-35$ & $3900 \pm 40$ & $"$ & GIN-12649 \\
\hline $2003-3$ & 185 & $110-120$ & $5460 \pm 50$ & $"$ & GIN-12648 \\
\hline 2004-6 & 219 & $75-85$ & $4120 \pm 90$ & Sapropel & GIN-13135 \\
\hline
\end{tabular}

terrace. Many studies $[1,5,8,13,14]$ indicate that the level of large lakes such as Imandra, Umbozero, and Lovozero varied during the Holocene generally lowering due to both their discharge and differentiated tec- tonic movements. The successive formation of a system of terraces on the western coast of Umbozero Lake is evident from asynchronous commencement of peat accumulation at hypsometrically different surfaces 


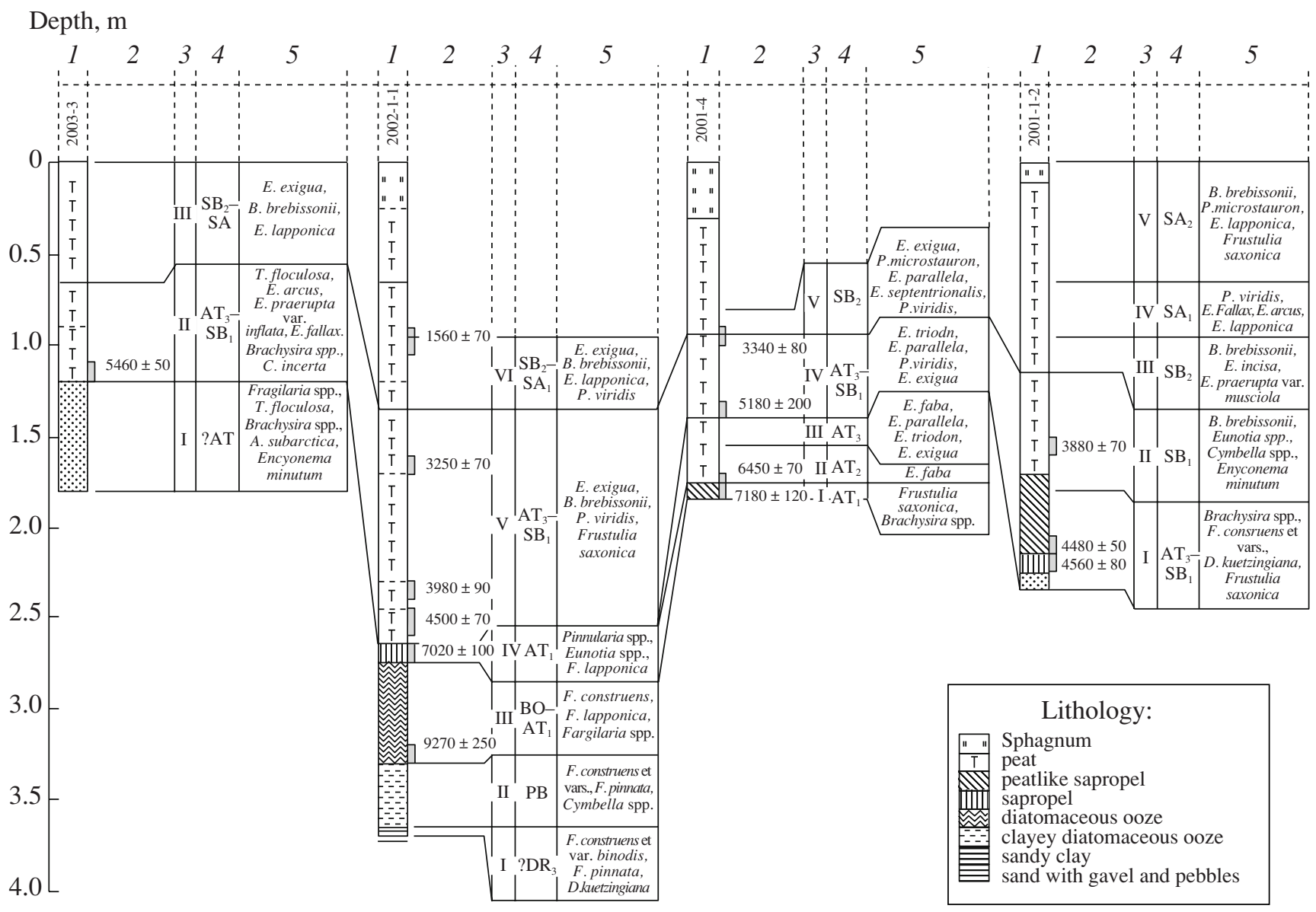

Fig. 2. Correlation of examined sections and main dominant species of diatom assemblages. (1) lithology; (2) radiocarbon age; (3) diatom zones; (4) Holocene periods; (5) dominant species.

(table). The Boreal period was marked by desiccation of the third and fourth terraces of Umbozero Lake, which is reflected in the change of diatom assemblages in the core section 2002-1. The second and first terraces became desiccated in the initial Atlantic and by the initial Subboreal periods, respectively.

The initial and middle Atlantic period (8.0 to $5.5 \mathrm{ka}$ ago). In sediments of the early Atlantic period, the abundance of diatom valves decreases against the background of their diversity reduction; ubiquitous species acquire the dominant role. Small residual lakes in moraine depressions and at the surface of Umbozero Lake terraces were subjected to intense overgrowing and swamping. The high degree of decomposition of herbaceous remains and large share of arboreal peat imply desiccation and forestation of available peats under conditions of the dry and relatively cold climate at the beginning of the Atlantic period, as is inferred from the palynological data $[3,5,12]$.

The terminal Atlantic-initial Subboreal period (5.5 to $3.2 \mathrm{ka}$ ago). This period was characterized by high concentration and taxonomic diversity of diatoms in sediments dominated by benthic forms. The onset of the period was marked by the maximal diversity of boreal diatom species. Peat accumulation resumed in moraine and drained lakes at the surface of Umbozero Lake terraces. Intense accumulation of peat and rapid lateral growth of bogs under conditions of the humid climate in the terminal Atlantic cold period was also noted by other researchers [4, 5, 9-11].

The late Subboreal-Subatlantic period (the last $3.2 \mathrm{ka}$ ) corresponded to new reduction in abundance and taxonomic diversity of diatom assemblages, which became oligodominant with prevalence of eurytopic species. Peat accumulation was discontinuous and characterized by very low rates in the late Subborealearly Subatlantic period; swamping of the area under consideration and peat formation intensified in the second half of the Subatlantic period. According to the palynological data $[3,5,12]$, the late Subboreal period was marked by cooling and aridization, which was replaced by warming with low annual atmospheric precipitation in the initial Subatlantic period and, then, by new cooling and some moistening in the second half of the last period.

Thus, changes in the composition of diatom assemblages reflect evolution of sedimentation settings related to relief reorganizations, changes in the moisture regime and groundwater level, and progressive swamping of the area. The peat accumulation com- 
menced in the terminal Boreal-initial Atlantic period 8.0-7.5 ka ago and was irregular and discontinuous during the Holocene. The late Atlantic-initial Subboreal period was most favorable for peat formation.

\section{ACKNOWLEDGMENTS}

This work was supported by the Russian Foundation for Basic Research, project nos. 05-05-64872, 06-0565267.

\section{REFERENCES}

1. N. N. Armand, V. Ya. Evzerov, V. S. Gunova, and R. M. Lebedeva, in Basic Problems of Anthropogene Geomorphology and Stratigraphy of the Kola Peninsula (Nauka, Leningrd, 1969), pp. 80-85 [in Russian].

2. M. S. Boch, Botan. Zhurn. 74, 1747 (1989).

3. T. V. Vashchalova and V. A. Klimanov, Vestn. MGU, ser. 5. Geogr., No. 1, 84 (1987).

4. G. A. Elina and R. M. Lebedeva, in Development of Environments in the USSR during the Late Pleistocene and Holocene (Nauka, Moscow, 1982), pp. 148-154 [in Russian].

5. G. A. Elina, A. D. Likashov, and T. K. Yurkovskaya, Late Glacial Period and Holocene of Eastern Fennoscandia
(Paleovegetation and Paleogeography) (Petrozavodsk, 2005) [in Russian].

6. G. A. Elina, L. V. Filimonova, S. I. Grabovik, and V. I. Kostina, Trudy Karel. Nauch. Tsentra, Issue 8, 94 (2005).

7. L. Ya. Kagan, B. I. Koshechkin, and R. M. Lebedeva, in History of Lakes in the East European Plain (Nauka, St. Petersburg, 1992), pp. 21-26 [in Russian].

8. L. Ya. Kagan, R. M. Lebedeva, S. A. Strelkov, and V. V. Chizhikov, Priroda i Khozyaistvo Severa, Issue 7, 21 (1980).

9. K. V. Kremenetskii, T. V. Vashchalova, S. V. Goryachkin, et al., Bull. MOIP, Otd. Biol. 102 (3), 39 (1997).

10. K. V. Kremenetskii, T. V. Vashchalova, and L. D. Sulerzhitskii, in Topical Problems of Palynology at the Onset of the Third Millenium (IGiRGI, Moscow, 1999), pp. 160-167 [in Russian].

11. G. G. Matishov, A. Yu. Sharapova, G. A. Tarasov, et al., Doklady Erath Sciences 404, 646 (2005) [Dokl. Akad. Nauk 402, 534 (2005)].

12. O. S. Olyunina, I. A. Karevskaya, and M. V. Tsekina, in Current Problems of Paleofloristics, Paleophytogeography, and Phytostratigraphy (Geos, Moscow, 2005), pp. 92-93 [in Russian].

13. V. S. Poretskii, A. P. Zhouse, and V. S. Sheshukova, Trudy Geomorfolog. In-ta, Issue 8, 95 (1934).

14. S. V. Shvarev, Geomorfologiya, No. 4, 97 (2003). 